\title{
BEHAVIOUR AND CIRCADIAN RHYTHM OF THE FISH BATHYGOBIUS SOPORATOR VALENCIENNES (GOBIIDAE) UNDER THE INFLUENCE OF ENVIRONMENTAL SALINITY AND TEMPERATURE
}

\author{
Edith Fanta ${ }^{1}$
}

\begin{abstract}
The behavioural patterns and their circadian rhythms may be adaptive to the peculiar environmental conditions of subtropical brackish waters where $\mathrm{Ba}$ thygobius soporator Valenciennes, 1837 live. Adult fish were caught at the southern Brazilian coast from mangrove rivers and rocky shores in a bay, where temperature and water salinity vary during the day and through the year. Observation on the behaviour of the animals was undertaken in salinity $8.5 \mathrm{ppt}, 17.0 \mathrm{ppt}, 25.5 \mathrm{ppt}$ and $34.0 \mathrm{ppt}$, each one in temperatures of $18^{\circ} \mathrm{C}$ and $28^{\circ} \mathrm{C}$. Temperature and salinity affect the frequency and intensity of some of the behavioural events, more than its pattern or rhythm. Swimming is rare, decreasing along the day and with temperature increase, being even lower at low salinity; aggressiveness is the highest in the morning being not affected by temperature, but by salinity, being higher the higher it is; territory defence decreases along the day and is lower at high temperature and extreme salinities; fish hide more at high temperature and with the decrease of salinity, but this is not rhythmical; a higher proportion of fish rest in vertical position when salinity and temperature are high, increasing slightly at the beginning of the afternoon; respiratory frequency increases with temperature, salinity and in the afternoon; the colour of the fish is mainly light with spots in all hours of the day and in all temperatures and different levels of salinity, but with a tendency of the presence of some dark fish during the morning and some light ones in the afternoon, showing a higher variability of colours at low temperature and extreme salinities. Besides temperature, salinity and light, feeding seems to be one of the determinant factors for the performance of the typical behaviour of $B$. soporator.

KEY WORDS. Bathygobius soporator, fish, behaviour, circadian rhythm, salinity, temperature
\end{abstract}

Fish that live in mangrove regions, rocky shores or tide pools often undergo sudden and frequent changes in environmental temperature and salinity, depending on climatic conditions (BUlger 1984; BULGER \& TREMAINE 1985; FANTA-FEOFILOFF et al. 1986). In subtropical and temperate regions rainy or dry summers or winters may signify water salinity ranging from $0.5 \mathrm{ppt}$ to $34 \mathrm{ppt}$, and temperatures from $5^{\circ} \mathrm{C}$ up to $35^{\circ} \mathrm{C}$, in all possible combinations. Not only the seasons of the year promote weather changes but, depending on local geography, sudden modified environmental conditions are observed in one and the same day. Thus, selective forces allowed some species with structural and physiological adaptations to live in such regions.

1) Departamento de Biologia Celular, Universidade Federal do Paraná. Caixa Postal 19031, 81531-970 Curitiba, Paraná, Brasil. 
Bathygobius soporator Valenciennes, 1837 is a very common Teleostean fish of the family Gobiidae, with a wide distribution from Venezuela to the southern Brazilian coast (MENEZES \& FIGUEIREDO 1976), occurring mainly in regions with environmental characteristics as described above, often in shallow brackish water. It is a small species, mostly carnivorous, with the typical behaviour of benthonic fishes. One of its popular names is "Maria-da-toca" meaning Mary-in-the-hole and referring to its commonness and to the fact that these fish often remain hidden in holes and under stones. From times to times, local fishermen report their apparent disappearance and in other times they are frequently observed and even easily caught by hand.

These folklore considerations lead us to the supposition that, besides morpho-physiological specific characteristics acquired along the evolution, the behaviour of this species might have adapted to each one of the environmental situations that they face along the day or the year, as occurs with other fish in the same region (FANTA-FEOFILOFF et al. 1986). The group Gobioidei is in middle of an evolutionary process, and the 600 known species occupy many different environments, except for the pelagic and abyssal, showing many different feeding habits, and varied morphological and physiological adaptations: they are eurythermic, euryhaline, resistant to desiccation and to asphyxia (LAGLER et al. 1962; NORMAN \& GREENWOOD 1974).

In order to understand better the behavioural dynamics, fish tests with different combinations of salinity and temperature became necessary, a method used before (FANTA-FEOFILOFF et al. 1986; FANTA 1995; FANTA et al. 1995).

As was often observed, the behaviour is related to the environmental quality (CRAWSHAW 1977; FANTA-FEOFILOFF 1983; FANTA-FEOFILOFF et al. 1983, 1986; FANTA et al. 1989a,b, 1990, 1994; FRY 1947, 1964, 1971; THORPE 1978). Thus, the objectives were to (I) determine which behavioural items change significantly and consistently under the influence of salinity and temperature, (II) if salinity and temperature affect the circadian rhythm of some behavioural features and (III) if behaviour is useful for predictions about the consequences of global climatic alterations.

The results of our analysis, in a sublethal physiological range of temperature and salinity, may reduce the subjectiveness in the interpretation of the reasons for distribution and occurrence of this species in certain coastal regions. Scientific support is also given to conservation programs or rearing purposes, bringing to attention the important relation between environmental conditions and the behaviour of fish.

\section{MATERIAL AND METHODS}

Adult Bathygobius soporator were obtained from a mangrove river at Pontal do Sul, Pontal do Paraná, Paraná, southern Brazil, where a high variability in the physic-chemical composition of the environment is observed (Fig. 1). In order to detect possible effects of temperature and salinity along the hours of the day on the fish behavior, tests in the laboratory were done. 128 individuals of both sexes, with 


\section{VARIABLE ENVIRONMENT}
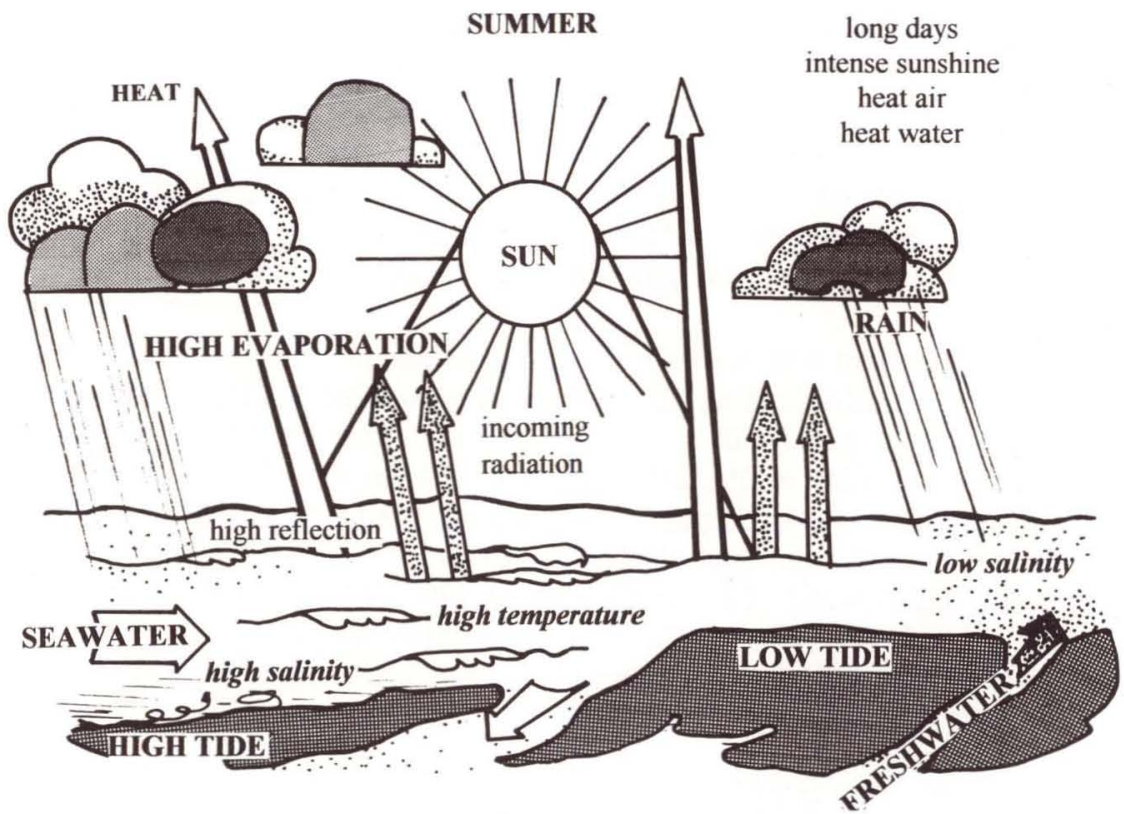

low sun short days weak sunshine

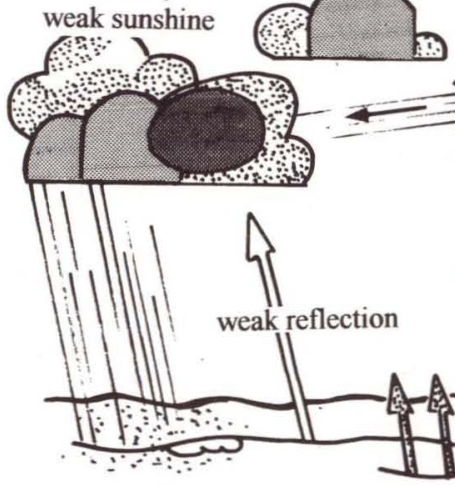

WINTER

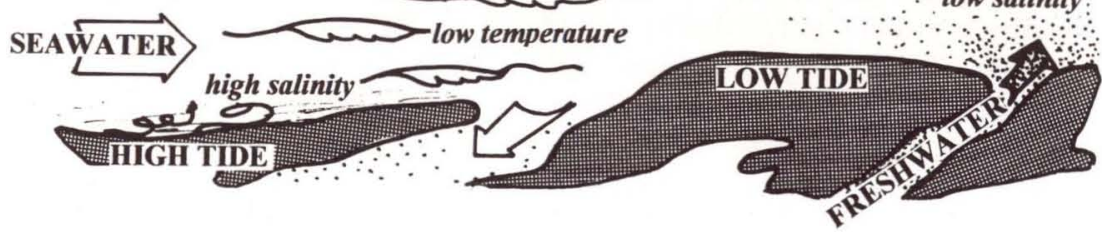

Fig. 1. Schematic summarised view of the variable environmental conditions in the nature, where Bathygobius soporator were caught, leading to different integration between the hour of the day, the salinity and the temperature, all of them affecting the fish behaviour. 
mean standard length of $9.4 \mathrm{~cm}( \pm 2.0 \mathrm{~cm})$, were obtained in early june and selected for acclimation during three weeks to the laboratory. After this period, preliminary studies were done for detection of behavioural variables for healthy adults, through direct observation. After confirmation of within observer and between observer reliability and the definition of suitable recording methods, a check sheet with all action patterns and an ethogram of the species typical behaviour were constructed. Decision was made for focal sampling, what means observing each individual and the group for a specific amount of time, recording all instances of its behaviour: 10 minutes of observation was the minimum time that allowed a consistent result for this species.

The treatment was designed for two variables in each test - salinity and temperature -, whilst holding all other conditions constant. The experimental aquariums were prepared with sea water diluted with filtered and dechlorinated tap water in the proportion of $0 \%, 25 \%, 50 \%$ and $75 \%$, resulting in salinity $34.0 \mathrm{ppt}$ (parts per thousand) (S1), 25.5ppt (S2), 17.0ppt (S3) and 8.5ppt (S4), respectively. The salinity was measured by an electrode connected to a salinometer and calibrated with Kopenhagen water. The temperature of $18^{\circ} \mathrm{C}\left( \pm 1^{\circ} \mathrm{C}\right)(\mathrm{T} 1)$ was the room temperature and $28^{\circ} \mathrm{C}\left( \pm 0.5^{\circ} \mathrm{C}\right)(\mathrm{T} 2)$ was obtained through heaters controlled by a thermostat. For such fish tests, no control aquariums can be organised, as far as there is no control situation, even in the nature.

The design of the experiments and the testing procedure was modified from FANTA-FEOFILOFF et al. (1986) (Fig. 2), being adapted to the characteristics of $B$. soporator. Series of eight 80 litres aquariums, with four individuals in each, were prepared. The bottom was covered with coarse sand and a brick with four holes providing a possible separate shelter for each individual fish. A constant photoperiod of 10 hours light/14 hours dark was offered, as well as a lighter (160 lux) and a darker (10 lux) region close to the bottom in each aquarium. The lateral walls of the aquariums were covered with green sheets (FANTA 1995) to provide a neutral background and to avoid lateral visual contact between fish of different aquariums. The front wall was divided in $10 \mathrm{~cm}$ squares, allowing a numerical evaluation of movements and definition of the relative position of each experimental fish. A shield, internally covered with a green sheet, provided with a small slit, allowed observation without interfering with the behaviour of the animals (Fig. 2). The fish are carnivorous (IHERING 1968). As determined by previous studies, the fish were fed with little sardine fillet fragments every two days, two hours after the beginning of the period of light, as this was the preferential feeding time. It was observed that these fish are more active during the day. Thus, direct observations of all four individuals of each group, in each one of the eight aquariums, were made every hour during the light period, and the results grouped in two hour periods $(\mathrm{H} 1, \mathrm{H} 2, \mathrm{H} 3$, $\mathrm{H} 4, \mathrm{H} 5)$. All data that were registered in the check sheets and transferred to the ethogram, being the validity and significance of numerical results statistically evaluated with the aid of Statistica for Windows 4.2. The sample size or number of individuals studied in each experimental situation (e.g. T1S1; T1S2; T1S3... T2S4) is $\mathrm{n}=16$, and the repeated measurements for each individual in each of the 40 variables (e.g. T1S1H1, T1S1H2, T1S1H3... T2S4H5) are $\mathrm{k}=50$. 

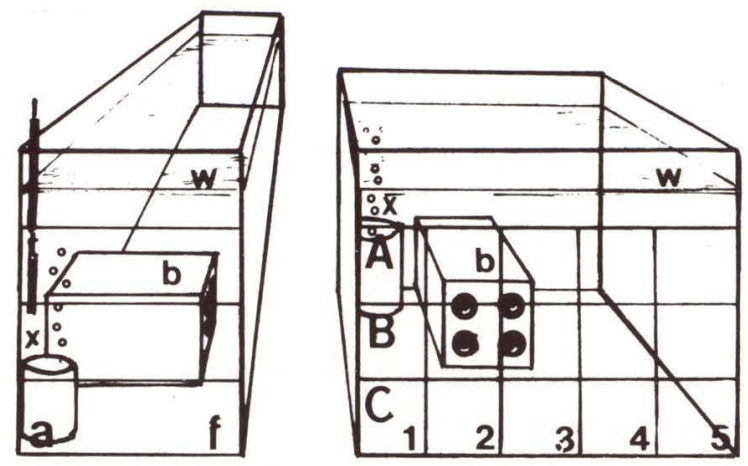

\section{B.s.}
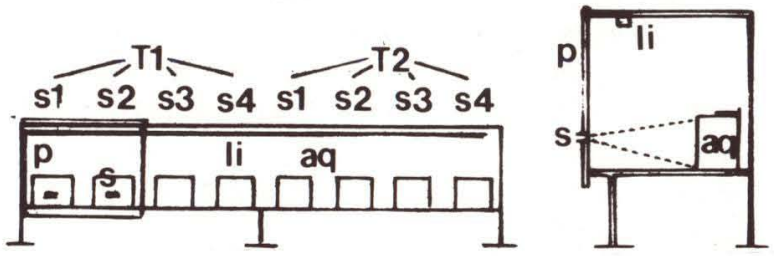

Fig. 2. The experimental arrangement in which some of the environmental factors as photoperiod (10 light/14 dark), summer and winter water temperature and four salinities were tested under controll. In (A) the lateral view of one aquarium showing $(w)$ the water surface, $(b)$ the position of the brick for shelter, $(x)$ the internal filter, (f) the light region, (a) the shadow region. In (B) the frontal view of one of the aquariums, showing the $10 \times 10 \mathrm{~cm}$ squares dividing the front wall in regions 1 to 5 and $A$ to $C,(w)$ the water surface, $(x)$ the filter and $(b)$ the brick with four holes for shelter. In (c) the arrangement of 8 aquariums (aq), for each one of the tests, with salinities $34 \mathrm{ppm}(\mathrm{S} 1), 25.5 \mathrm{ppm}(\mathrm{S} 2), 17 \mathrm{ppm}\left(\mathrm{S} 3\right.$ ) and $8.5 \mathrm{ppm}(\mathrm{S} 4)$, and temperatures of $18^{\circ} \mathrm{C}$ (T1) and $28^{\circ} \mathrm{C}$ (T2), upper light (li) providing a photoperiod of 10 hours light and 14 hours dark, each two aquariums being protected by a shield $(p)$, provided with an observation slit $(s)$ in front of each aquarium. In (D) the lateral view of the relative position of the aquarium (aq), the light beam (li), the protection shield ( $p$ ) and the observation slit (s). B.s. shows the size of the mean Bathygobius soporator, in the same scale as (A) and (B).

The behaviour was described and the following behavioural features were registered and numerically evaluated: (I) respiratory frequency: number of opercular movements per minute, always in resting animals, when out of the holes; (II) colour: percentage of individuals considered dark when deep brown, dark with spots when deep brown with black stripes and spots, medium when brown, medium with spots when brown with dark brown or black stripes and spots, light when ochre, light with spots when yellowish with light brown pattern, pale when light yellowish; (III) Motility: comprised the percent of animals in swimming activity or when fish were only changing their resting place moving at least a distance equal to the body length; (IV) preferential region: percentage of individuals in lighter or darker regions when resting; (V) hiding: percentage of animals that were hidden in holes or in another shelter as e.g. behind the filter; (VI) resting (including sleeping): percentage of time that fish remained motionless, alert or not to the environment; (VII) aggression 
(including persecutions): percentage of animals that performed any aggressive action; (VIII) territory defence: percentage of animals defending an area in or out of a shelter; (IX) vertical position: percentage of animals resting with the head upwards, leaning against a substrate.

\section{RESULTS}

\section{General observations on species specific behaviour of $\boldsymbol{B}$. soporator}

Preliminary studies on the behaviour of Bathygobius soporator allowed the detection of those aspects of the behaviour that are typical for the species and that might be affected by salinity and temperature or vary along the day. Some behavioural features displayed by $B$. soporator are species specific and not dependent on the environmental salinity and temperature conditions, at least in the physiological range herein tested. Thus, what was different from one tested situation to the other was mostly the intensity and/or the frequency of some behavioural feature in different temperature and/or salinity, but not the type of performance itself.

Bathygobius soporator is a typical sedentary benthic species. It reposes for long periods and $30 \%$ of this time in shelters. Enough holes were offered for hiding and so it was observed that these fish preferred to remain alone in the shelter, rarely with another individual. The same behaviour was observed when the fish were unprotected, as they usually rested alone, rarely grouped. They remained always in contact with a horizontal substrate. Only $4.77 \%$ of the fish rested in a vertical position, the head upwards, leaning on a vertical support, with the aid of the pelvic fins. When resting out of a shelter, $61.5 \%$ of the individuals preferred lighter regions and not the shadow.

Resting was interrupted by short periods of swimming. The swimming movements were always fast, lasting in average for $1.2 \%$, rarely $3 \%$, of the total time. Activity can be apparently spontaneous, but was often related to search for food. Spontaneous activity generally started when one fish left a shelter. Usually its first action was the persecution of another individual that, as a consequence, became pale and fled. This action was the starter for other persecutions in the whole group, even for the fleeing fish that sometimes persecuted some other individual for short periods of time.

Sometimes a kind of social hierarchy could be seen: considering four individuals, there was usually one dominant fish that persecuted all other fish and two other that persecuted only one in the group, always the same individual that was the weakest in the social hierarchy. The persecutor always became dark and the persecuted fish pale. Often one fish suddenly left a shelter, persecuted an individual and returned to the original place again. Very rarely it changed the hole or resting place. But in all cases, aggressiveness was very low indeed.

Another kind of activity of $B$. soporator was related to search for food. It happened mostly during the light period, mainly at the first hours after the beginning of the day. It was observed that, when one individual accidentally or through direct action found food and started feeding, it induced the same activity in the whole 
group. The releaser seemed to be the typical feeding movement of the first fish. During periods of feeding activity, they became restless, the percent of time in swimming increased slightly and most of them remained dark. Tremor of the whole body was frequent and the respiration became faster only during the actual catch of food. Feeding was strongly related to swimming and aggressions, persecutions and territory defence. At the end of feeding activity, as soon as all individuals took enough food, all aggression stoped, territories were no more defended and all animals rested, far from each other, for longer periods, most of them returning to their former positions.

The typical colour of this species was light with spots $(58.8 \%$ of the individuals), being lighter $(12.1 \%)$ or darker $(13.8 \%)$ individuals mainly those involved in aggressive actions like persecutions and fleeing, and dominance of territory. The aggressor or dominant became dark and the opponent light.

Bathygobius soporator remained alert for long periods of time, showing erected fins and searching eye movements while remaining in repose. Aggressions started even in the holes, when more than one fish shared the same shelter. Suddenly, without apparent reason, one individual started to make some sinuous body movements, leading the other or others to leave the hole. Those who left were not allowed to return to it. Often the fleeing fish had even to remain at least at a distance of three times the body length from the holes, as the fish in the shelter defended a territory, not allowing it to approximate. When general aggression level was high in the group, two fish often displayed frontally to each other, opening the mouth slowly, and keeping it open for a certain period. This attitude resulted in lightening and fleeing of one of the opponents.

Territory defence was very low and not always clear. Sometimes the more aggressive individuals in the group established an area corresponding to a diameter of three times the body length, that was defended temporarily. In repose, they observed all fish and persecuted all individuals that came near to the border of this area. This behaviour was rare but often connected to feeding activity. In other periods, mainly in the afternoon, when well fed, the same fish was seen lying side by side with other fish.

The respiration could only be observed in resting animals and when they were out of the holes. The opercular movements were always flat and regular.

\section{Influence of salinity and temperature on the behaviour of $B$. soporator}

The highest proportion of the time this species rested, motionless. The percentage of fish resting in light regions increased with the temperature (Fig. 3) and the salinity (Fig. 4) increase. For all combinations of water salinity and temperature, there was a certain individual variability.

The mean amount of fish resting in vertical position was three times higher $(6.7 \%)$ at $28^{\circ} \mathrm{C}$ (Fig. 3 ) and the higher the salinity, the higher is the proportion of animals in this position (6.9\%) (Fig. 4).

When resting out of a shelter most part of the fish prefer not to rest grouped. Although, there is a tendency of grouping more when salinity (Fig. 4) and temperature (Fig. 3) are low. 


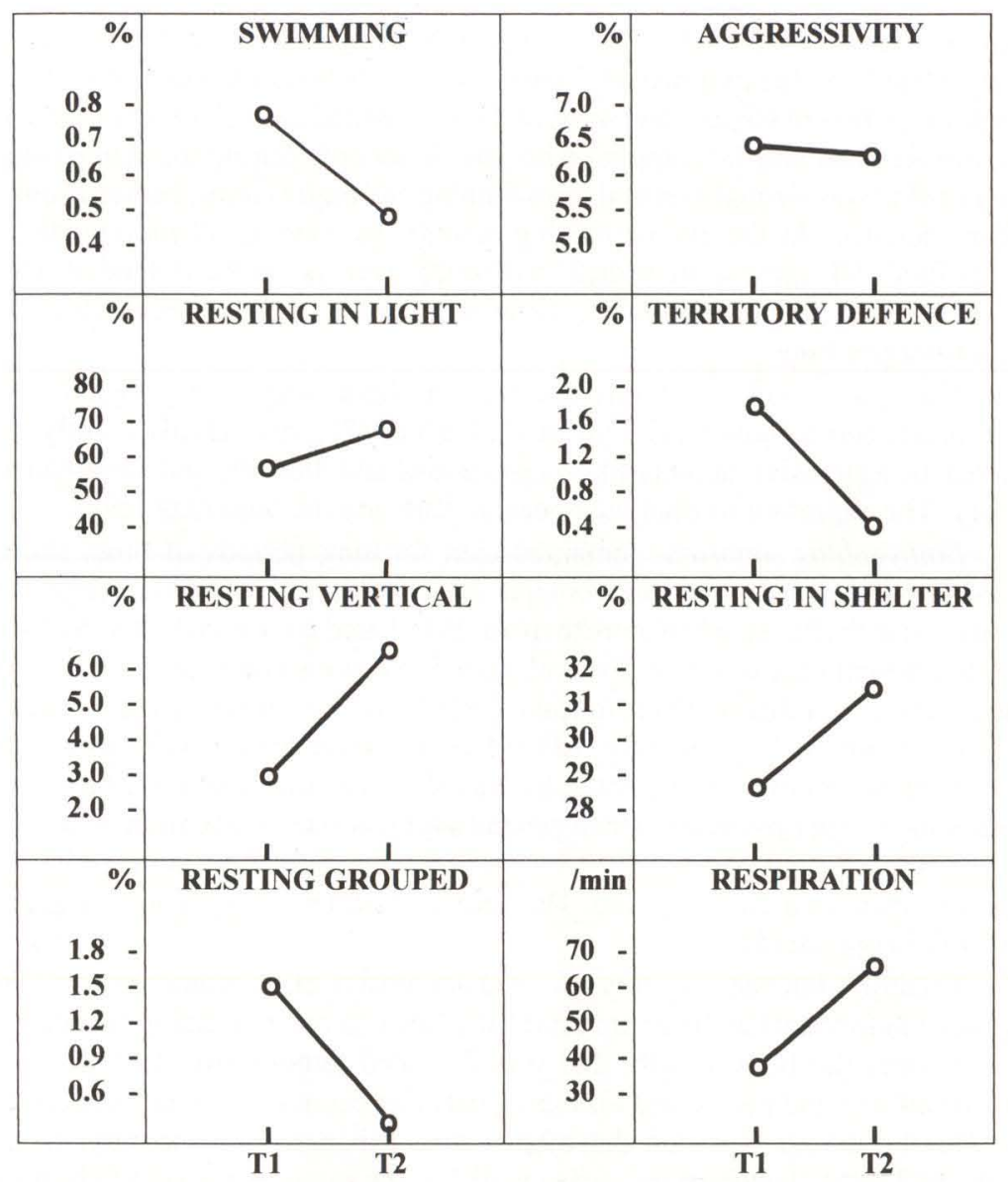

Fig. 3. Influence of temperature on some of the behavioural features of Bathygobius soporator like respiration (frequency in mean opercular movements/minute), grouped fish (\%), hidden fish (\%), fish defending territory (\%), aggressive fish (\%) and swimming (\%). The temperatures $\mathrm{T} 1$ and $\mathrm{T} 2$ are, respectively $18^{\circ} \mathrm{C}$ and $28^{\circ} \mathrm{C}$.

Swimming was performed during a very small proportion of time and the difference in levels of the time spent in swimming activity, in different combinations of water salinity and temperature, are minor. In any case, it is more influenced by temperature than by salinity. Even being low in general, the swimming activity decreases with the increase of temperature, from $0.78 \%$ to $0.49 \%$ (Fig. 3). In all salinities it is very low, being the highest at $25.5 \mathrm{ppt}$ and the lower ones at extreme salinities (Fig. 4). The lowest value lies at $28^{\circ} \mathrm{C}$ and $17 \mathrm{ppt}$ and the highest at $18^{\circ} \mathrm{C}$ and 25.5ppt. The last one shows a variance of 1.41, standard deviation 1.19 and standard error 0.53 . The smallest variance occurs at the temperature of $28^{\circ} \mathrm{C}$ and salinity $8.5 \mathrm{ppt}$. 


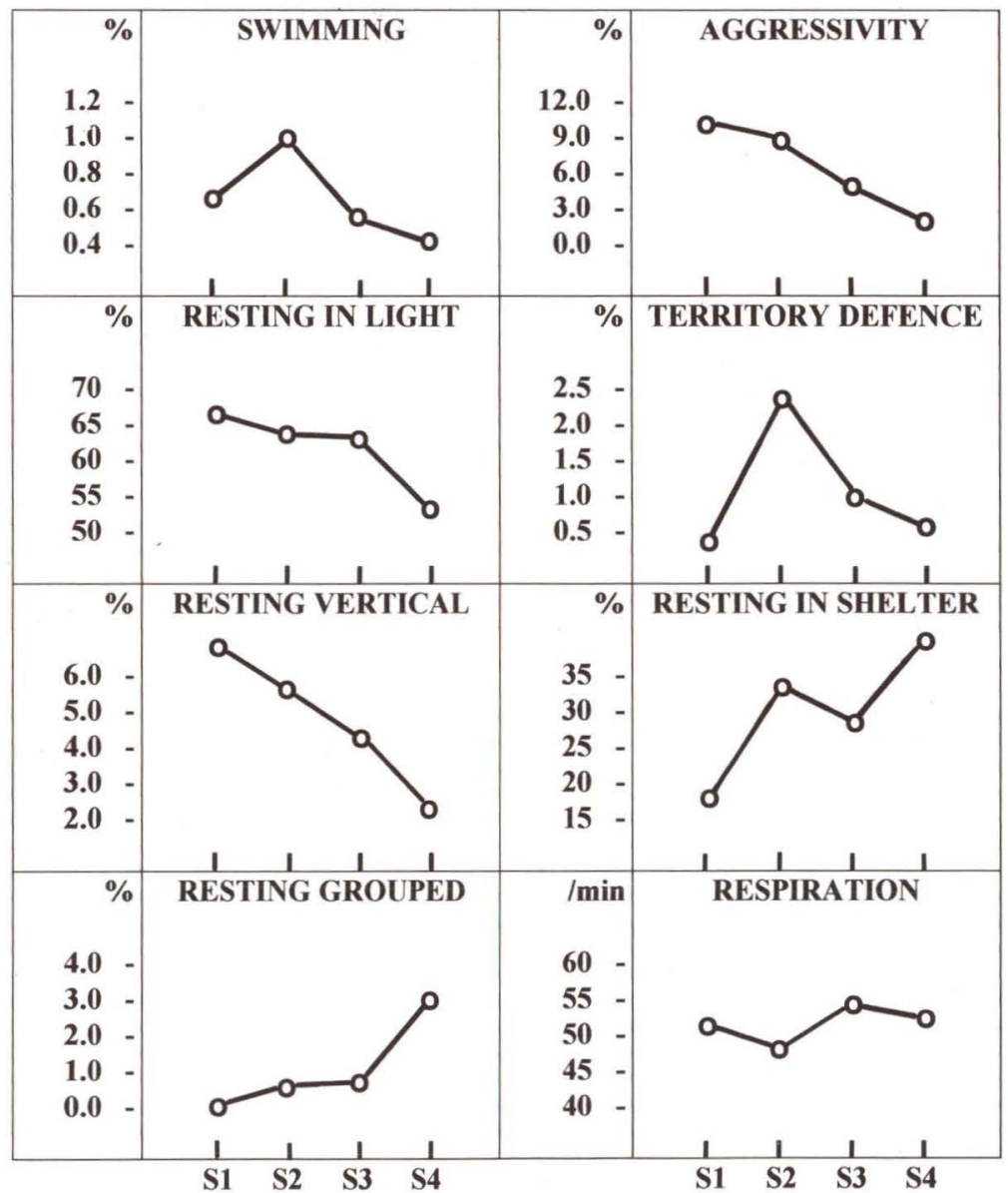

Fig. 4. Influence of salinity on some of the behavioural features of Bathygobius soporator like respiration (frequency in mean opercular movements/minute), grouped fish (\%), hidden fish (\%), fish defending territory (\%), aggressive fish (\%) and swimming (\%). S1, S2, S3 and S4 are respectively the salinities $34 \mathrm{ppt}, 25.5 \mathrm{ppt}, 17 \mathrm{ppt}$ and $8.5 \mathrm{ppt}$.

Aggressiveness was very low and not influenced by the temperature (Fig. 3 ), but decreased with water salinity decrease from $10.19 \%$ at $34 \mathrm{ppt}$ to $1.63 \%$ at 8.5ppt (Fig. 4). At high salinity variance was high (58.36), the standard deviation being 7.83 and the standard error 2.41 .

Territory defence, on the other hand, is temperature dependant, being higher at low temperature, paralleling swimming activity (Fig. 3). The highest values are observed at $25.5 \mathrm{ppt}$ and $18^{\circ} \mathrm{C}(2.37 \%)$. Extreme salinities caused lower levels for territory defence and the highest was obtained at 25.5ppt (Fig. 4) as occurred for swimming. 


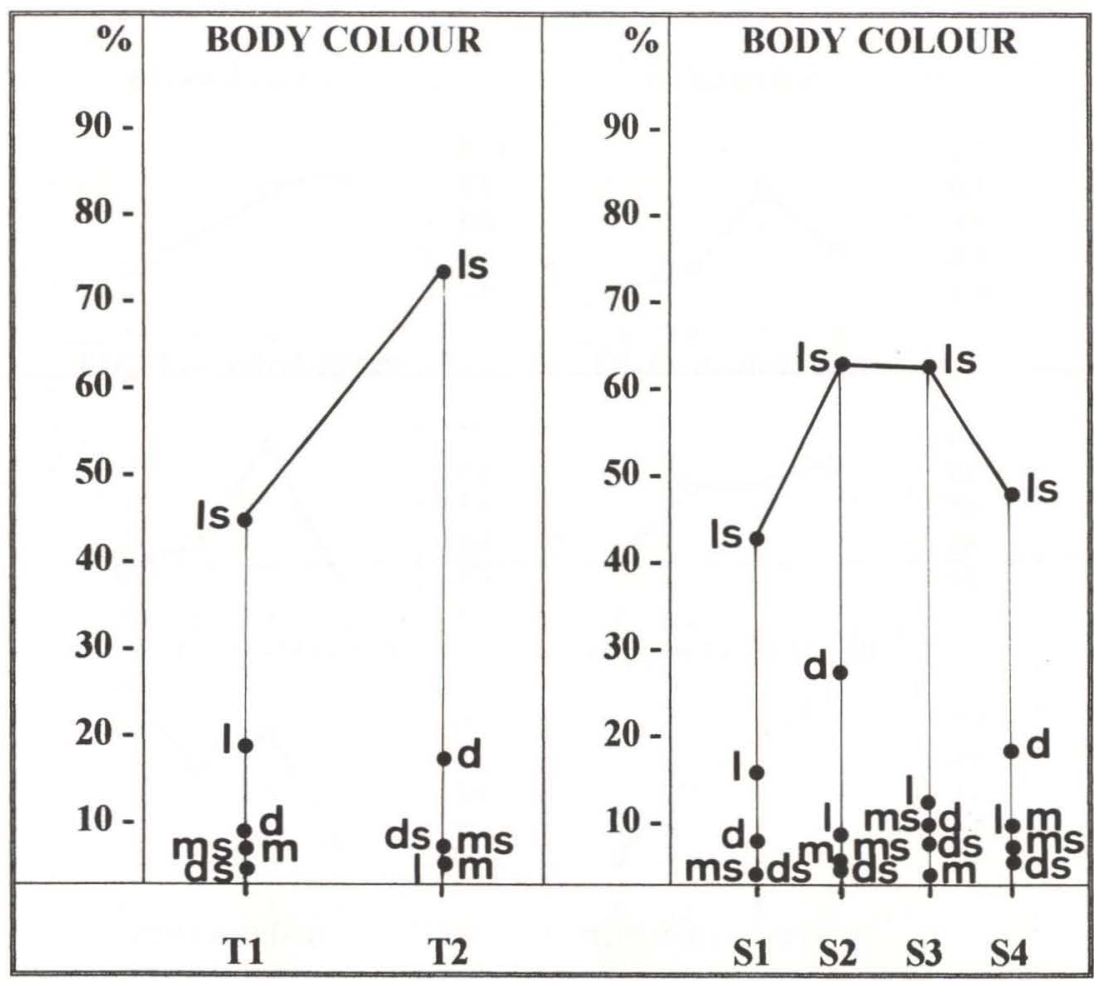

Fig. 5. Effect of temperature and salinity on the percentage of body color in Bathygobius soporator. light (I), light with spots and stripes (Is), medium ( $\mathrm{m})$, medium with stripes and spots (ms), dark (d) and dark with spots and stripes (ds).

A slightly higher proportion of fish $(31.11 \%)$ rested in a shelter at $28^{\circ} \mathrm{C}$ than at $18^{\circ} \mathrm{C}(28.32 \%)$ (Fig. 3$)$ increasing when water salinity decreased, from $17.2 \%$ to $39.85 \%$ (Fig. 4). The lowest value was found at $28^{\circ} \mathrm{C}$ and $34 \mathrm{ppt}$, and at $18^{\circ} \mathrm{C}$ and $25.5 \mathrm{ppt}$, and the highest at $28^{\circ} \mathrm{C}$ and $25.5 \mathrm{ppt}$.

Respiration was less influenced by water salinity showing a positive correlation with temperature, being the mean respiratory frequency at $18^{\circ} \mathrm{C} 39.25 / \mathrm{min}$ and at $28^{\circ} \mathrm{C} 62.97 / \mathrm{min}$. But at higher temperatures the variance is higher (98.9) when compared to that at low temperatures (44.5) (Fig. 3). Salinity, on the other hand, induced only slight changes, in a very narrow range. There was a general tendency for a lower respiratory frequency in higher salinities, but the lowest value was obtained at 25.5ppt and the highest at 17ppt (Fig. 4). Considering both temperatures and all salinities, the Q10 was between 1.4 and 1.7, indicating a temperature induced phenomenon.

The colour of fish was light with spots, in a high proportion at the temperature of $28^{\circ} \mathrm{C}(72.09 \%)$ and less high at $18^{\circ} \mathrm{C}(45.53 \%)$. In extreme salinities the colours were more variable, with a tendency of the occurrence of some dark fish when 
salinity is $25.5 \mathrm{ppt}$ and $8.5 \mathrm{ppt}$ in high temperature and some light ones at $34 \mathrm{ppt}$ and $17 \mathrm{ppt}$ when the temperature was low (Fig. 5).

\section{Circadian rhythm under the influence of salinity and temperature}

- Not all activities were rhythmical along the day. Motility and resting, aggressiveness and territory defence as well as the respiratory frequency were the most significant ones.

The swimming activity was rhythmical along the day, often in connection with the search for food. One has to take into consideration that, in all cases, values were so low that its differences are minor. But in general, higher values were seen in the morning and there was a peak at $\mathrm{H} 1$ and $\mathrm{H} 2$, having been the lowest value observed in the afternoon, mainly at $\mathrm{H} 4$ with a slight tendency to increase at the end of the light period (Fig. 6). Mainly in the morning the shape of the curves was similar, but the mean levels for each time period varied with salinity and temperature.

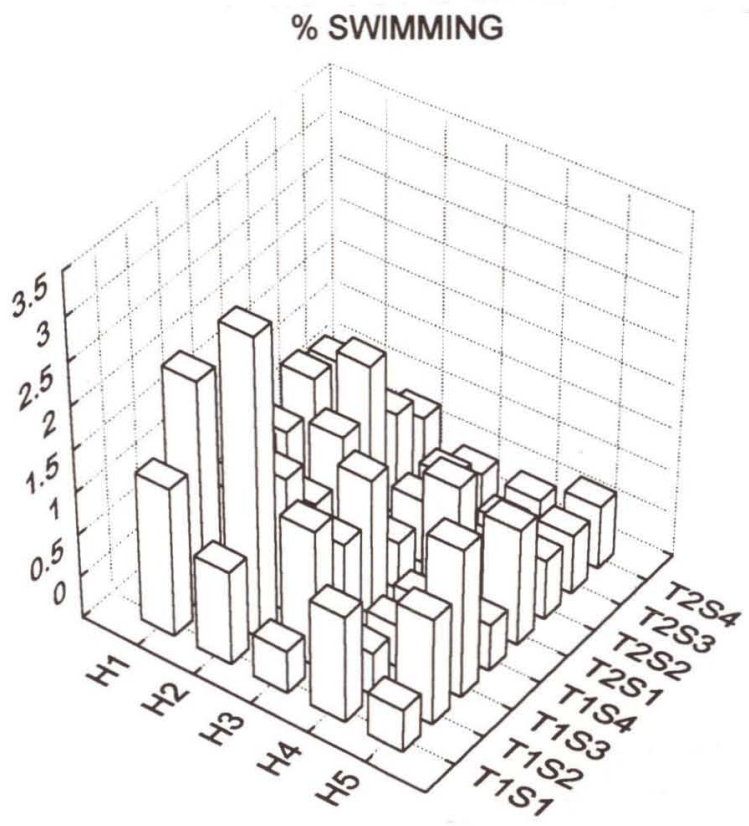

Fig. 6. Graphical representation of the interactive effect of temperature, salinity and the hour of the day on the swimming performance (\% of animals) of Bathygobius soporator. The times ( $\mathrm{H} 1$ to $\mathrm{H} 5)$ start at the beginning of the light period, each one covering a two hours period consecutively. The temperatures $\mathrm{T} 1$ and $\mathrm{T} 2$ are, respectively $18^{\circ} \mathrm{C}$ and $28^{\circ} \mathrm{C}$. S1, S2, S3 and S4 are respectively the salinities $34 \mathrm{ppt}, 25.5 \mathrm{ppt}, 17 \mathrm{ppt}$ and $8.5 \mathrm{ppt}$.

Resting in holes showed a slight tendency to decrease from the morning to the afternoon, but not significantly (Fig. 7). Resting out of holes with a preference for shadow or light showed no variation or rhythm along the day. Repose in vertical position was slightly higher at noon and the beginning of the afternoon and the 
lowest values were obtained at the end of the day, but all values were very low. This rhythm was certainly influenced by temperature and salinity. Resting grouped was very rare and seemed to be random except for the situation of low temperature and salinity when fish were induced to remain grouped in the afternoon (Fig. 7).
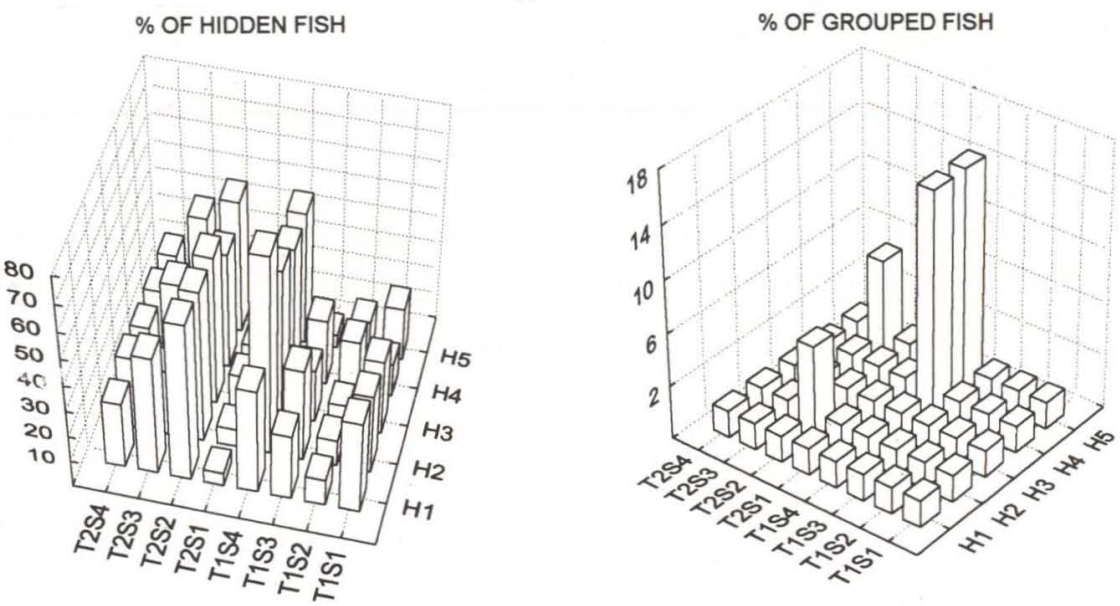

\% OF AGGRESSIVE FISH

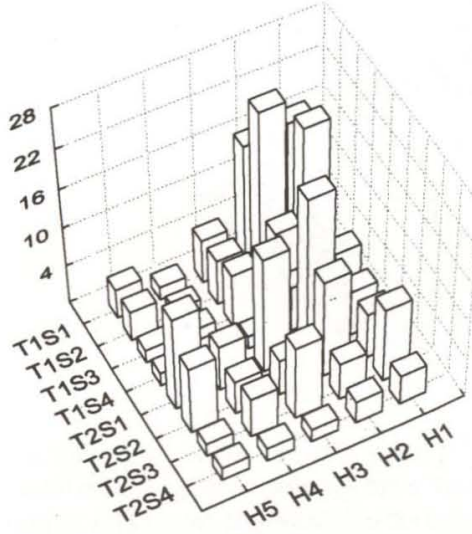

$\%$ OF FISH DEFENDING TERRITORY

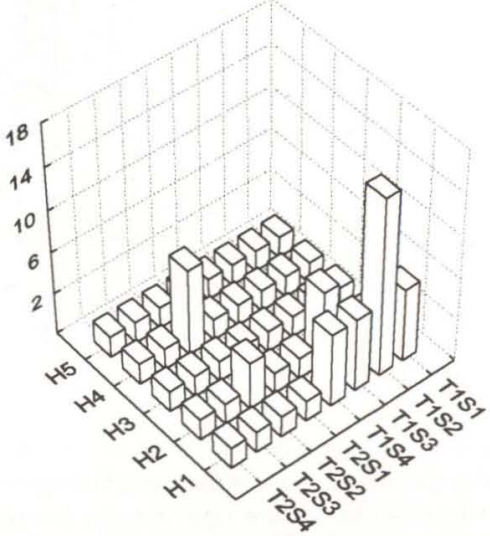

Fig. 7. Graphical representation of the interaction of temperature and salinity, at different hours of the day, inducing the level of each of the following behavioural features of Bathygobius soporator. hidden fish (\%), grouped fish (\%), aggressive fish (\%) and fish defending territory (\%). The times ( $\mathrm{H} 1$ to $\mathrm{H} 5)$ start at the beginning of the light period, each one covering a two hours period consecutively. The temperatures $\mathrm{T} 1$ and $\mathrm{T} 2$ are, respectively $18^{\circ} \mathrm{C}$ and $28^{\circ} \mathrm{C}$. S1, $\mathrm{S} 2, \mathrm{~S} 3$ and S4 are respectively the salinities 34ppt, 25.5ppt, 17ppt and 8.5ppt. 
Aggressiveness was always higher in the morning, the highest values having been obtained at $\mathrm{H} 2$ and the lowest in the afternoon at $\mathrm{H} 4$ with a slight tendency to increase at the end of the day. The shape of the curves was similar for all combinations of salinity and temperature, but differences between highest and lowest values varied in different salinities. Territory defence was the highest early in the morning, but only at low temperature, decreasing along the day, seeming to be related to search for food. In salinity $25.5 \mathrm{ppt}$ the highest values were obtained for both temperatures (Fig. 7).

Respiration is rhythmical along the day. During the morning the levels of respiratory frequency are lower, even considering that the animals are more active during this period. During the afternoon the levels are higher, being the highest observed at $\mathrm{H} 4$, falling slowly at the end of the day. Temperature strongly affected the level of respiratory frequency, but the shape of the curve remained the same along the day. Slight variation was seen in different salinities, but consistently higher values were obtained in the afternoon (Fig. 8).

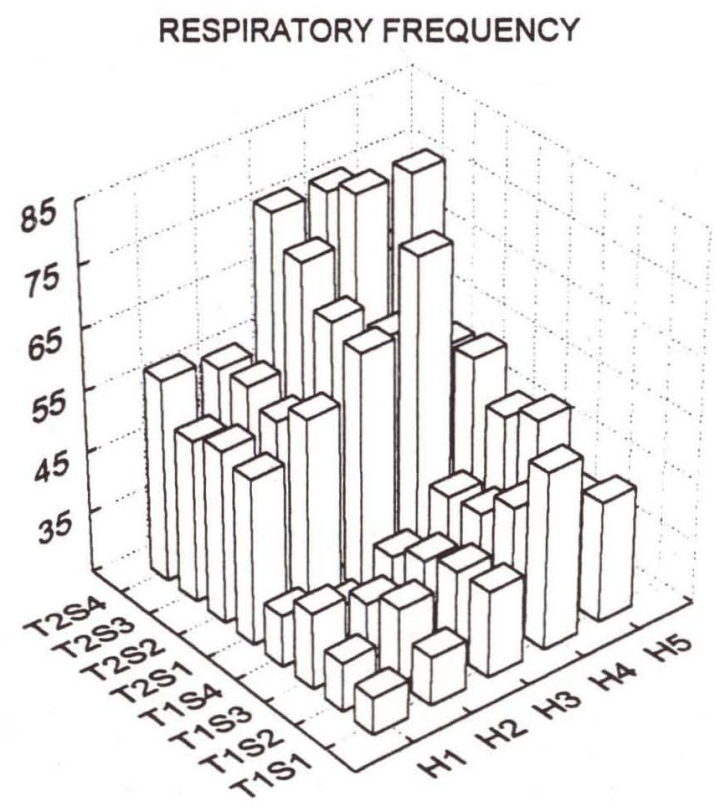

Fig. 8. Graphical representation of the interactive effect of temperature, salinity and the hour of the day on the respiratory frequency (number of opercular movements/minute) of Bathygobius soporator. The times $(\mathrm{H} 1$ to $\mathrm{H} 5)$ start at the beginning of the light period, each one covering a two hours period consecutively. The temperatures $\mathrm{T} 1$ and $\mathrm{T} 2$ are, respectively $18^{\circ} \mathrm{C}$ and $28^{\circ} \mathrm{C}$. S1, S2, S3 and S4 are respectively the salinities 34ppt, 25.5ppt, 17ppt and 8.5ppt.

The colour was predominantly light with spots along the whole day and in all environmental conditions (Fig. 9), but there was a slight tendency of having some darker fish at high temperature in the morning at $\mathrm{H} 1$ and $\mathrm{H} 2$ and lighter ones at low 
temperature in the afternoon at $\mathrm{H} 4$ and $\mathrm{H} 5$. This seemed to be in direct relation with the increased activity during the morning. For each salinity with each temperature differences may be seen in the frequency of each color along the day (Figs 10-11).

\section{BODY COLOR (\% OF ANIMALS) MEAN TEMPERATURE AND SALINITY}

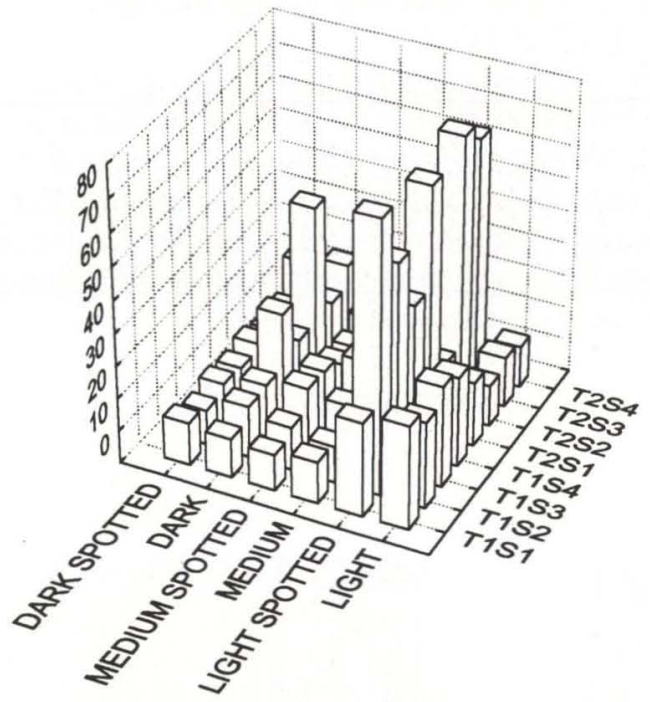

Fig. 9. Graphical representation of the body colour of Bathygobius soporator (\% of animals) in different combinations of temperature and salinity. The temperatures T1 and T2 are, respectively $18^{\circ} \mathrm{C}$ and $28^{\circ} \mathrm{C}$. S1, S2, S3 and S4 are respectively the salinities $34 \mathrm{ppt}, 25.5 \mathrm{ppt}, 17 \mathrm{ppt}$ and 8.5ppt.

\section{DISCUSSION}

It is well known that the sub-order Gobioidei is now in evolution and that the existing species occupy almost all possible biotopes, except for the pelagic and abyssal regions. They are known for eurythermie, euryhalynity, resistance to desiccation and hypoxia. A great variability of food is taken by the group as well. As a consequence of its adaptive complexity, the interpretation of experimental results obtained for the Gobioidei are more difficult.

The role of physical factors and chemical nature of the environment is important in the life of fish (FANTA 1994). The water temperature is an environmental controlling factor (FRY 1971; LOVE 1970, 1980) determining the rate of metabolic processes (BULGER 1984; FANTA-FEOFILOFF 1983; HOCHACHKA \& SOMERO 1984; LUCCHIARI et al. 1988; NIKOLSKI 1963) and the behaviour of fish (FANTAFEOFILOFF 1983; FANTA-FEOFILOFF et al. 1983; FANTA et al. 1989a,b; HESS 1952; OlLA \& STUDHOLME 1975; Olla et al. 1978; PATERSON \& ANDERSON 1969) at a significant extent. The light is another direct as well as secondary determinant factor 


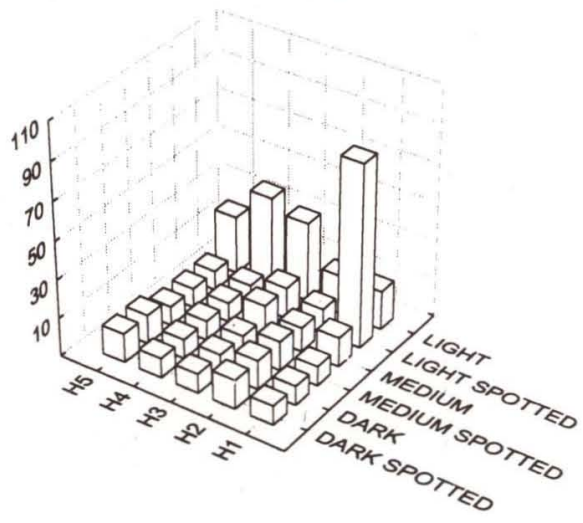

T1 S3

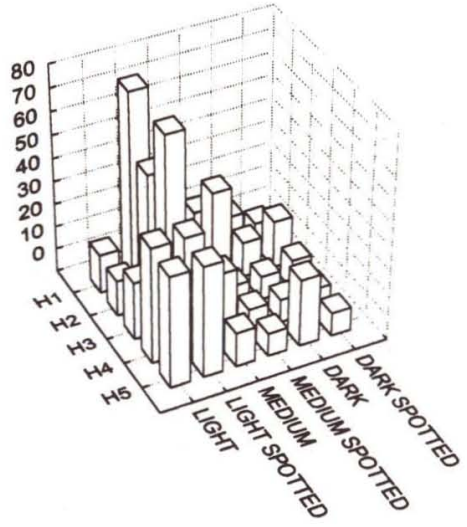

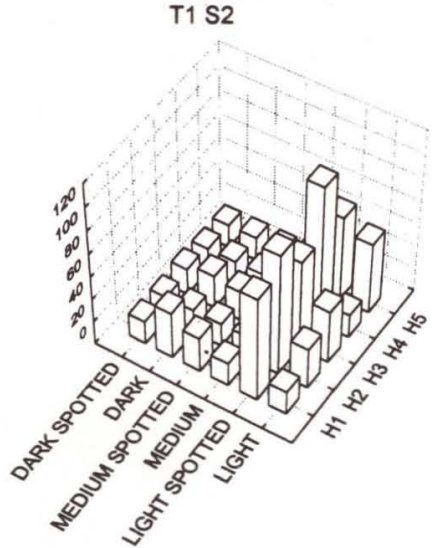

T1 S4

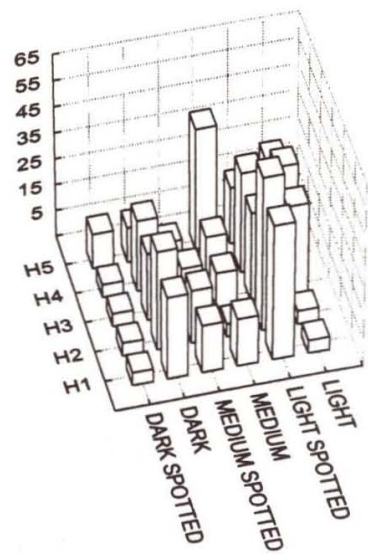

Fig. 10. Graphical representation of the body colour of Bathygobius soporator (\% of animals) for each of the combinations of the temperature $\mathrm{T} 1\left(18^{\circ} \mathrm{C}\right)$ and the salinities $\mathrm{S} 1, \mathrm{~S} 2, \mathrm{~S} 3$ and S4, respectively 34ppt, 25.5ppt, 17ppt and $8.5 \mathrm{ppt}$. The times $(\mathrm{H} 1$ to $\mathrm{H} 5)$ start the beginning of the light period, each one covering a two hours period consecutively.

(DAVIS \& BARDACH 1965; FANTA et al. 1990, 1994; SWIFT 1965), often integrated to some other variables (MCClAnAHAN et al. 1986; PICKERING 1981). Other properties of water, such as salinity, are also of great importance, influencing the distribution, the physiology and the behaviour of many fish species (FITZGERALD 1985; FANTA-FEOFILOFF et al. 1986; FANTA et al. 1995; MCCLANAHAN et al. 1986).

Estuarine habitats are often harsh because besides seasonally defined climatic conditions there are also daily thermal and saline fluctuations, in part due to abrupt weather change and the effect of high and low tide. These are the characteristics of the regions where Bathygobius soporator occur normally (Fig. 1). In such regions like subtropical and temperate mangrove and coastal shallow estuaries, 
this species must be totally adapted to the frequent environmental impacts caused by water temperature and salinity. This happens also in marsh areas as described by BULGER (1984).

T2 S1

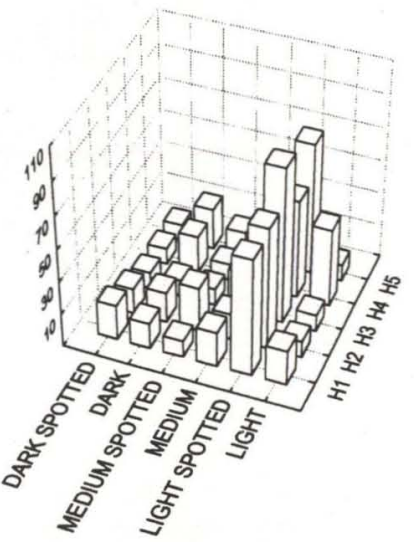

T2 S3

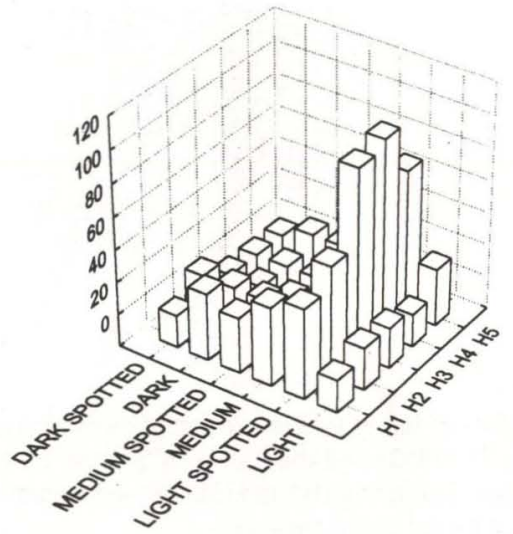

T2 S2

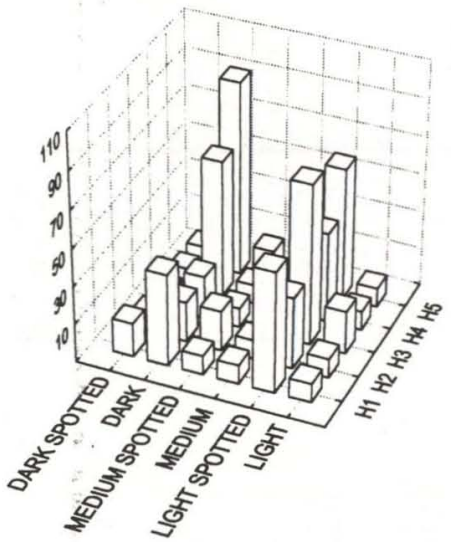

T2 S4

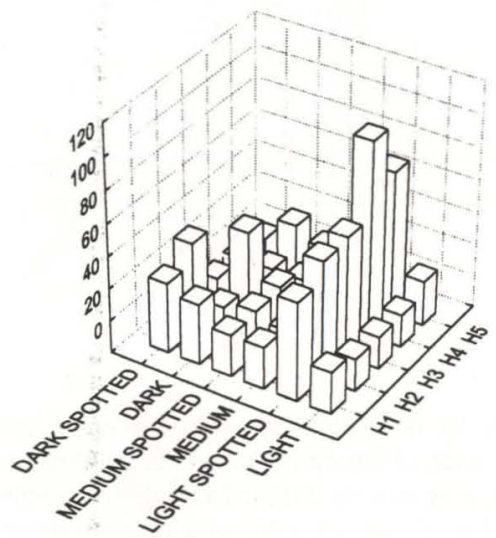

Fig. 11. Graphical representation of the body colour of Bathygobius soporator (\% of animals) for each of the combinations of the temperature $\mathrm{T} 2\left(28^{\circ} \mathrm{C}\right)$ and the salinity $\mathrm{S} 1, \mathrm{~S} 2, \mathrm{~S} 3$ and $\mathrm{S} 4$, respectively $34 \mathrm{ppt}, 25.5 \mathrm{ppt}, 17 \mathrm{ppt}$ and $8.5 \mathrm{ppt}$. The times $(\mathrm{H} 1$ to $\mathrm{H} 5)$ start at the beginning of the light period, each one covering a two hours period consecutively.

When fish perceive some environmental perturbation, the initial response is mainly a behavioural one, often including escape. If the effect persists, and avoidance is not within the normal strategy of the animal, biochemical and physiological changes must occur to guarantee the homeostasis, reflecting the organisms genetic adaptation (PICKERING 1981). Such effects may, again, be expressed externally in the behaviour of the organism (OLLA et al. 1978; FANTA et al. 1995). 
Being eurythermal and euryhaline, B. soporator has developed along its evolution physiological strategies to survive in variable environments. Therefore, this species is a good tool for the establishment of relations between behavioural adaptations and water quality. Only in the laboratory the evaluation of the influence of each one of the chosen factors is possible, as environmental conditions can be simulated and kept under control. It is also possible to observe the behaviour of the fish at will. Afterwards, the results on the behavioural adaptations to each situation may be interpreted in the light of the corresponding environmental situation in the nature. Appropriate methods and evaluation of behaviour have to be chosen (MARTIN \& BATESON 1993). Besides being useful in testing the effects of different chemical and physical parameters, what includes some pollutants (FANTA 1991, 1994; SILVA et al. 1993; SPIESER 1978), fish tests often allow a better knowledge of the biology of some species as for example the Antarctic notothenids Notothenia neglecta, N. rossi-marmorata, Trematomus bernacchii (FANTA et al. 1989b), Gobionotothen gibberifrons and Trematomus newnesi (FANTA et al. 1995) making possible some predictions about the consequences of global climatic changes. It allows also some practical advise for fish rearing or repopulating purposes as for the catfish Genidens genidens (FANTA-FEOFILOFF et al. 1983), Pimelodus maculatus, Rhamdia hilarii and Nannorhamdia guttata (FANTA-FEOFILOFF 1983), or the mullet Mugil curema (FANTA-FEOFILOFF et al. 1986).

Clearly, adaptation to thermal and saline extremes and the capacity to react to relatively rapid temperature and salinity changes is important for the survival of the species. These factors induce the level of the behavioural performance of the fish. The capacity of $B$. soporator to show many strategies or adaptations to the changes they face frequently avoids that they have to change place every time when the environmental conditions are altered. This happens also with other species adapted to changeable environment as Tautoga onitis that depends upon finding suitable shelter and food resources in their normal homerange for survival (OLLA et al. 1978).

B. soporator shows the behaviour of a typically benthonic fish. They repose the most part of the time in all whether conditions keeping always the contact with a substrate, mostly horizontally, rarely vertical with the head upwards. They may hide or not and show some social interaction, mostly related to feeding activity. In general, social interactions and group interactions are not independent, are varied but not well quantified (FENDERSON et al. 1968) being observed either in the laboratory (ALEE et al. 1948; WELTY 1934) or in the nature (BAIRD 1968; JENKINS 1969). Social interaction is not frequent in B. soporator, and always temporary, being aggressiveness usually very low. They show typical group feeding, induced by the action and type of movements of one of the individuals in the group. This activates the whole group that starts searching for food. This is what NEWMAN (1956) and ALBRECHT (1966) called an activation of intragroup agonistic behaviour. As soon as feeding ends, B. soporator keep in repose and aggressiveness becomes almost non-existent. This is the opposite as generally observed, as social facilitation or co-operation during prey location is usually followed by more intense aggression shortly after feeding in many species, as e.g. Gadus morhua (BRAWN 1961, 1969). 
Activity and behaviour of an animal, as well as its related physiological processes are often rhythmic. Knowledge on the relation of the external cycle to the behaviour is essential to understanding the harmony between organisms and environment (OLLA \& STUDHOLME 1971). On the other hand, for B. soporator, besides the influence of the photo-period on the behaviour, it was seen that sometimes the action of the temperature or the salinity superimposes the drives of the internal clock.

The rhythm of certain activities like swimming and aggressiveness seem to be a direct consequence of the beginning of the light period, as the highest values were seen along the four initial hours of the day. They may be also related to the preferential feeding time, indifferently to the presence of food. Before the actual feeding activity starts and aggressiveness becomes higher, it seems to be a predisposition for feeding which is revealed through the higher values of territory defence at the beginning of the light period. So, light probably induces this first action that will be than followed by the other actions that culminate with feeding, if there is food present. In the afternoon, all these behavioural actions become very low. The higher activity in the morning is a known phenomenon (SCHWASSMANN 1971; THORPE 1978) and occurs with many different species. But, besides that, temperature is often a regulator to swimming and aggressiveness that usually increase with temperature (HESS 1952). Aggressiveness of $B$. soporator does not vary with winter or summer temperatures, except for territory defence that is higher in the winter, but more connected to salinity changes, being the highest always in rainy seasons and low tide, what means low salinity.

Swimming of $B$. soporator is often higher during the winter, mainly when salinities are not extreme. Other fish like Gobius show a variation of their cruising speed with the temperature (LAGLER et al. 1962) and many species are less active during the winter being the increased activity often driven by longer summer days or light periods (PROSSER 1965; SwIFT 1965). In the case of the fish tests with $B$. soporator, the light period was kept constant. So, the duration of the light period was not another variable that could influence the results, making therefore possible an evaluation of the isolated action of the two variables temperature and salinity. In any case, even keeping the light regime constant, the periods after the start of the light has a great importance for the fish and is, in a certain way, a third variable.

In many fish, activity is depressed at higher temperatures (FRY 1947, 1971; PATERSON \& ANDERSON 1969). For Tautoga onitis it was advantageous to make all necessary adjustments to the environmental conditions and so, be able to remain within their normal homerange as their survival would depend upon finding suitable shelter and food resources (OlLA et al. 1978). Activity decreased as a secondary consequence to hypoxia when low salinities were reached in $T$. newnesi and $G$. gibberifrons (FANTA et al. 1995). Reduction or lowering of activity and closer association with shelter may be brought about by nightfall or by an environmental stress such as elevated temperature (OlLA \& STUDHOLME 1971). Closer shelter association evidently protects the fish from predation while responsiveness is impaired.

Resting in shelters is apparently random along the day, and depending on environmental salinity and temperature. It is more common in summer with heavy 
rain falls and low tide, when temperature is high and salinity is low and the lowest when during the summer dryness and high tide make the salinity rise to high values, or during the winter with high tide. Hiding in a shelter is apparently not connected to the preparation for feeding even considering that the shelter is a kind of territory. Although, during the feeding period the fish may suddenly leave the shelter, feed and quickly return to the place of origin. Summer temperature induces less territory defence as well as less swimming.

Thus, "Mary-in-the-hole" is an appropriate name only for some definite periods of the day or climatic conditions. It is also characteristic for only more or less half of the time, as far as $B$. soporator prefer lighter regions out of shelter, some in vertical position, during the summer with high tide and so, high salinity. During the winter, on the other hand, the swimming activity increases a bit, the fish tend to remain more in the shadow and sometimes grouped in the afternoon, mainly at low tide and rainy periods. For some species, as the Antarctic Notothenia neglecta, to rest grouped seems to protect the smaller individuals from predators, as they are then part of a darker bigger being, not being distinguished as individuals in the group (FANTA et al. in press). This may be also connected to the offer of food that may vary and to the transparency of the water providing more or less protection to the fish. During the winter, when temperature is low, and in extreme salinities, light individuals might be observed, mainly during the afternoon. In a general way, when activity, aggressiveness and territory defence are higher the fish rest isolated, as this includes the time when they are in feeding activity, and concurrence for food seems to exist.

There is no apparent advantage in resting in a vertical position, besides that in the nature, depending on the place where they occur, there is perhaps not enough shelter or horizontal resting place, mainly in rocky shores. Thus, this may be an evolutionary advantage, seeming not to have a strong correlation with the water quality. It is slightly higher at noon, after the cessation of feeding activity higher in the summer with high tide and high evaporation.

Respiration shows an unexpected tendency to be low in the morning and higher in the afternoon, consistently, for all environmental conditions. Perhaps the need for digesting the food and recovering from the higher activity or confirmation of social hierarchy requires more energy than the activity itself. On the other hand one has to consider that the respiration is always measured in resting animals, therefore eliminating from the calculations the levels that might have been reached by $B$. soporator while active, aggressive or feeding. A clear cycle of oxygen consumption can be often seen (FANTA et al. 1990; FANTA-FEOFILOFF 1983). In Mugil curema the lowest oxygen consumption was at $8.5 \mathrm{ppt}$ and the highest survival rate, indicating the lowest stress situation (FANTA-FEOFILOFF et al. 1986). G. gibberifrons shows the lowest respiratory frequency the higher is the salinity as well as yawning and surfacing (FANTA et al. 1995), two behavioural attitudes that were not observed in $B$. soporator.

When extreme salinities are obtained, through high tide with sunshine or low tide with rain, the colour of $B$. soporator is more variable. When active they become darker, mainly when aggressive behaviour is performed, and lighter when they 
assume a recessive position in the social hierarchy or are non aggressive. So, the body colour is more related to activity. As activities are often variable according to changes in the environmental factors, the relation between the environmental quality and the body colour of these fish is an indirect or a secondary one. But the amount of darker or lighter fish will depend on the water temperature being more dark fish seen in the summer and more light ones in the winter. But, during high temperatures, when the animals are less active, the most part of them shows light spotted colour, that mimics better the environment. N.G. gibberifrons is lighter in low salinities and darker in high ones (FANTA et al. 1995). Light colour for darker fish and darker colour for lighter fish often is an indication for stress (FANTA-FEOFILOFF et al. 1983; FANTA et al. 1989a,b; PICKERING 1981).

Notorious is the individual variability. This is quite usual when behaviour is studied and more than that, quantified. Not only all environmental factors interact, but also no consideration was given to sex, developmental stage and dominance, because this is the real situation in the nature, if we want to understand what happens with a group of this species, as a whole.

One can conclude from this study that the behavioural items of $B$. soporator that change significantly and consistently under the influence of temperature and salinity are the respiration, swimming and accordingly resting and territory defence and the body colour. The other behavioural actions are only slightly variable. Extreme salinities are apparently stressing in a certain level, interfering with the effects of the light regimen or the temperature. So, temperature affects directly the respiration, swimming performance, resting and territory defence.

For this species behaviour is not useful for the prediction of consequences of climatic alterations as a whole as the local climatic changes occur within hours and this species shows a wide range of behavioural adaptations.

Summarising what seems to happen in the nature as a consequence of a variable environment (Fig. 12) one can imagine that, during the summer, when the mean temperature is high during high tide and sunshine, the animals like to be in the holes, but when out of the shelter they repose in lighter regions, showing low swimming activity, often keeping vertical position and being dark in colour, therefore, some being easily caught. This situation changes when heavy rains diminish the salinity, and probably also the transparency of the water and the presence of food, causing even higher hiding. This is a typical situation when "Mary-in-the-hole" disappears, according to the fishermen. At low tide, when salinity decreases by the income of river fresh water ad the cloudy weather diminishes the evaporation, swimming, territory defence and aggressiveness are the lowest. Low tide and rain causes more dark fish and greater colour variability. This behaviour guarantees not only protection but also a very low energy consume and may also be connected to the availability of food in the nature. It might be also a defence against predators, because water is low and predation even by birds may be higher.

During the winter, temperatures can fall even below the tested one, the days are sometimes darker, swimming activity and territory defence are higher and those fish that are not spotted tend to be light. Rains with high tide cause the highest 
swimming values and the lowest hiding, perhaps because usually the income of food is higher. Rains with low tide cause some fish to become dark, some remain in shelters and the highest amount of grouped individuals, with less variable colour.

Thus, very simple changes in the behaviour enhance feeding possibilities, diminish predation and avoid energy loss and stronger impacts of the environment.

\begin{tabular}{|c|c|c|c|c|c|c|c|c|c|c|c|c|}
\hline \multirow{3}{*}{ ENVIRONMENT } & \multirow{2}{*}{\multicolumn{6}{|c|}{$\begin{array}{c}\text { W I } \\
\text { high tide }\end{array}$}} & \multicolumn{2}{|c|}{$\mathrm{S} \quad \mathrm{U}$} & \multirow[t]{2}{*}{$M$} & \multirow{2}{*}{\multicolumn{2}{|c|}{$\begin{array}{|cc|}\text { M } & \mathrm{E} \\
\text { low tide }\end{array}$}} & \multirow[t]{2}{*}{$\mathbf{R}$} \\
\hline & & & & & & & high & tide & & & & \\
\hline & sun & clouds & rain & sun & clouds & rain & sun & clouds & rain & sun & clouds & rain \\
\hline BEHAVIOUR & $\begin{array}{l}\text { T18 } \\
\text { S34 }\end{array}$ & $\begin{array}{l}\text { T18 } \\
\text { S34 } \\
\text { S17 }\end{array}$ & $\begin{array}{c}\text { T18 } \\
\text { S25.5 } \\
\text { S17 }\end{array}$ & $\begin{array}{c}\text { T18 } \\
\text { S25.5 } \\
\text { S17 }\end{array}$ & $\begin{array}{c}\text { T18 } \\
\text { S17 } \\
\text { S8.5 }\end{array}$ & $\begin{array}{l}\text { T18 } \\
\text { S8.5 }\end{array}$ & $\begin{array}{l}\text { T28 } \\
\text { S34 }\end{array}$ & $\begin{array}{l}\text { T28 } \\
\text { S34 }\end{array}$ & $\begin{array}{c}\text { T28 } \\
\text { S25.5 } \\
\text { S17 }\end{array}$ & \begin{tabular}{c|}
$\mathrm{T} 28$ \\
$\mathrm{~S} 25.5$
\end{tabular} & $\begin{array}{l}\text { T28 } \\
\text { S17 }\end{array}$ & $\begin{array}{l}\text { T28 } \\
\text { S8.5 }\end{array}$ \\
\hline $\begin{array}{l}\text { SWIMMING } \\
\text { ACTIVITY }\end{array}$ & & & & & & & & & & & & \\
\hline $\begin{array}{c}\text { AGGRESSIVE- } \\
\text { NESS }\end{array}$ & & & & & & & & & & & & \\
\hline $\begin{array}{c}\text { TERRITORY } \\
\text { DEFENSE }\end{array}$ & & & & & & & & & & & & \\
\hline $\begin{array}{l}\text { RESTING } \\
\text { VERTICAL }\end{array}$ & & & & & & & & & & & & \\
\hline $\begin{array}{l}\text { RESTING } \\
\text { GROUPED }\end{array}$ & & & & & & & & & & & & \\
\hline $\begin{array}{l}\text { RESTING } \\
\text { HIDDEN }\end{array}$ & & . & & & & & & & & & & \\
\hline $\begin{array}{l}\text { RESTING IN } \\
\text { LIGHT }\end{array}$ & & & & & & & & & & & & \\
\hline $\begin{array}{l}\text { RESPIRATORY } \\
\text { FREQUENCY }\end{array}$ & & & & & & & & & & & & \\
\hline $\begin{array}{l}\text { \% LIGHT } \\
\text { SPOTTED }\end{array}$ & & & & & & & & & & & & \\
\hline $\begin{array}{c}\text { \% DARK } \\
\text { FISH }\end{array}$ & & & & & & & & & & & & \\
\hline $\begin{array}{l}\% \text { LIGHT } \\
\text { FISH }\end{array}$ & & & & & & 帚動 & & & & $\underline{|l| l \mid}$ & & \\
\hline
\end{tabular}

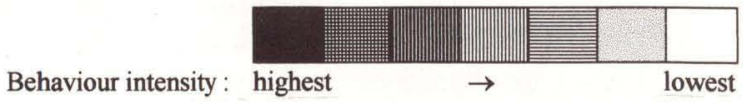

Fig. 12. Summary of the effects of the environmental conditions on the behaviour of Bathygobius soporator from the beginning of the light period. The temperatures are $18^{\circ} \mathrm{C}(\mathrm{T} 18)$ and $28^{\circ} \mathrm{C}$ (T28); the salinities are 34ppt (S34), 25.5ppt (S25.5), 17ppt (S17) and 8.5ppt (S8.5). The darker the shadow, the more intense is the behaviour performed.

ACKNOWLEDGEMENTS. The author wishes to thank CNPq for financial support to the laboratory of Environmental Impact Studies; J.L. Figueiredo (Museu de Zoologia, Universidade de São Paulo), for the systematic confirmation of the species; A.T. Boscardim, C.P.S. Greca and A.C.S. Greca for temporary technical assistance and A.T.B. Guimarães for computational help. 


\section{REFERENCES}

AlBreCHT, H. 1966. Zur Stammesgeschichte einiger Bewegungsweisen bei Fischen untersucht am Verhalten von Haplochromis (Pisces, Cichlidae). Z. Tierpsychol. 23: 270-301.

Alee, W.C.; B. GreenberG; G.M. Rosenthal \& P. FranK. 1948. Some effects of social organization on growth in the green sunfish Lepomis cyanellus. Jour. Exptl. Zool. 108: 1-20.

BAIRD, R.C. 1968. Aggressive behavior and social organization in Mollinesia latipinna Le Sueur. Texas Jour. Sci. 20: 157-176.

BRAWN, V.M. 1961. Aggressive behavior in the cod (Gadus callarias L.). Behaviour 18: 107-147.

1969. Feeding behavior of cod (Gadus morhua). Jour. Fish. Res. Board Can. 26: 583- 596.

BUlger, A.J. 1984. A daily rhythm in heat tolerance in the Salt Marsh Fish Fundulus heteroclitus. Jour. Exptl. Zool. 230: 11-16.

Bulger, A.T. \& S.C. TRemaine. 1985. Magnitude of seasonal effects on heat tolerance in Fundulus heteroclitus. Physiol. Zool. 58 (2): 197-204.

CRAWSHAW, L.I. 1977. Physiological and behavioral reactions of fishes to temperature change. Jour. Fish. Res. Board Can. 34: 730-739.

DAVIS, R.E. \& I.E. BARDACH. 1965. Time co-ordinated prefeeding activity in Fish. Animal Behavior 13 (1): 154-162.

FANTA, E. 1991. Ação de poluentes sobre tecidos, p.32-37. In: H.S.L. SANTOS (Ed.) Histologia de Peixes. São Paulo, FCAU-UNESP, 83p.

1994. Estudos de comportamento de Peixes dentro de um contexto multidisciplinar e sua aplicação prática. An. Soc. bras. Etologia 12: 14-29.

1995. Influence of background color on the behavior of the fish Oreochromis niloticus (Cichlidae). Arq. Biol. Tecnol. 38 (4): 1237-1251.

FANTA, E.; P.H. LUCCHIARI \& M. BACILA. 1989a. The effect of environmental O 2 and $\mathrm{CO}_{2}$ levels on the tissue oxygenation and the behavior of Antarctic fish. Comp. Biochem. Physiol. 93A (4): 819-831.

. 1989b. The effect of temperature increase on the behavior of Antarctic fish. Proc. NIPR Symp. Polar Biol. 2: 123-130.

1990. Circadian rhythm of oxygen consumption and oxygen levels in the muscle of Notothenia neglecta (Pisces, Teleostei). Comp. Biochem. Physiol. 96C (1): 151-155.

FANTA,E.; M.F. LuVIZOTTO \& A.A. MEYER. 1995. Gill structure of the Antarctic fishes Notothenia (Gobionotothen) gibberifrons and Trematomus newnesi, Nototheniidae, stressed by salinity changes and some behavioral consequences. Nankyoku shiryô (Antarctic Record) 39 (1): 25-39.

FANTA, E.; A.A. MEYER \& S.R. GRÖTZNER. (in press). On the feeding behavior of some Antarctic Nototheniidae fish. Nankyoku shiriô (Antarctic Record).

FANTA, E.; A.A. MEYER; S.R. GRÖTZNER \& M.F. LuvizotTo. 1994. Comparative study on feeding strategy and activity patterns of two Antarctic Fish: 
Trematomus newnesi Boulenger 1902 and Gobionotothen gibberifrons (Lönnberg, 1905) (Pisces, Nototheniidae) under different light conditions. Nankyoku Shiryô (Antarctic Record) 38 (1): 13-29.

FANTA-FEOFILOFF, E. 1983. Temperature and low oxygen tolerance in three species of fresh water Pimelodidae (Teleostei, Siluriformes). Arq. Biol. Tecnol., Curitiba, 26 (4): 495-507.

Fanta-FeofilofF, E.; D.R. DE B. Eiras; A.T. Boscardim \& M. LacerdaKRAMBECK. 1986. Effect of salinity on the behavior and oxygen consumption of Mugil curema (Pisces, Mugilidae). Physiol. and Behav. 36 (6): 1029-1034.

FANTA-FEOFILOFF, E.; N.S. TAKAHASHI \& A.T. BosCARDIM. 1983. Behavioral changes with temperature increase in the Ariidae Genidens genidens (Teleostei, Siluriformes). Arq. Biol. Tecnol., Curitiba, 26 (4): 535-544.

FEnderson, O.C.; W.H. EverharT \& K.M. MUTH. 1968. Comparative agonistic and feeding behavior of hatchery-reared and wild salmon in aquaria. Jour. Fish. Res. Board Can. 25: 1-14.

FItZGERALD, G.J. 1985. Salinity preferences of four sympatric species of Sticklebacks (Pisces: Gasterosteidae) during their reproductive season. Copeia 1: 209-213.

FRY, F.E.J. 1947. Effects of the environment on animal activity. Ontario Fish. Res. Lab. Publ. 68: 1-62.

1964. Animals in aquatic environment: Fishes, p.715-728. In: J. FIELD. (Ed.) Handbook of Physiology. Baltimore, Williams and Wilkins, 852p.

- 1971. The effect of environmental factors on the physiology of Fish, p.1-98. In: W.S. HOAR \& D.J. RANDALl (Ed.) Fish Physiology. New York, Academic Press, vol. 6.

HESS, E.H. 1952. Temperature as a regulator of the attach-response of Betta splendens. Z. Tierpsychol. 9 (1): 379-382.

HOCHACHKA, P.W. \& G.N. SOMERO. 1984. Biochemical adaptations. New Jersey, Princeton Univ. Press, 537p.

IHERING, R. VON. 1968. Dicionário dos Animais do Brasil. Brasília, Ed. Univ. Brasilia, 790p.

JENKINS JR., T.M. 1969. Social structure, position choice and microdistribution of two trout species (Salmo trutta and Salmo gairdneri) resident in mountain streams. Anim. Behav. Monogr. 2: 57-123.

LAGLER, K.F.; J.E. BARDACH \& R.R. MillER. 1962. Ichthyology. New York, J. Willey \& Sons, 545p.

Love, R.M. 1970. The chemical biology of Fishes. London, Acad. Press, 547p. 1980. The chemical biology of Fishes. Advances 1968-1977. New York, Acad. Press, vol. 2, 943p.

LUCCHIARI, P.H.; E. FANTA \& M. BACILA. 1988. The effect of temperature on the muscle oxygen levels in Antarctic fish. Proc. NIPR Symp. Polar Biol. 2: 117-122.

MARTin, P. \& P. BAteson. 1993. Measuring Behavior. Cambridge Univ. Press, 222p. 
McClanahan, L.L.; C.R. Feldmeth; J. Jones \& D. Soltz. 1986. Energetics, salinity and temperature tolerance in the mohave Tui Chub, Gila bicolor mohavensis. Copeia 1: 45-52.

Menezes, N.A. \& J.L. Figueiredo. 1976. Manual de Peixes marinhos do sudoeste do Brasil. Teleostei. São Paulo, Museu de Zoologia.

Newman, M.A. 1956. Social behavior and interspecific competition in two trout species. Physiol. Zool. 29: 64-81.

NiKOLSKI, G.V. 1963. The ecology of Fishes. New York, Acad. Press, 352p.

NoRMAN, J.R. \& P.H. GreENWOOD. 1974. A history of Fishes. London, Ernest Benn, 467p.

Olla, B.L. \& A.L. StudHolme. 1971. Daily and seasonal rhythms of activity in the bluefish (Pomatomus saltatrix), p.303-326. In: H.E. WINN \& B.L. OLLA (Ed). Behavior of Marine Animals 2. New York, Plenum Publ. Corp..

. 1975. The effect of temperature on the behavior of young tautog Tautoga onitis L. Proc. 9th Europ. Mar. Biol. Symp.: 75-93.

Olla, B.L.; A.L. Studholme; A.J. BejdA; C. SAmet \& A.D. Martin. 1978. Effect of temperature on activity and social behavior of the adult tautog Tautoga onitis under laboratory conditions. Marine Biology 45: 369-378.

PATERSON, R.H. \& J.M. ANDERSON. 1969. Influence of temperature change on spontaneous locomotor activity and oxygen consumption of Atlantic salmon Salmo salar acclimated to two temperatures. Jour. Fish. Res. Bd. Canada 26: 93-109.

PiCKERING, A.D. 1981. Stress and Fish. London, Acad. Press, 367p.

PROSSER, C.L. 1965. Theory of physiological adaptation on poikilotherms to heat and cold. Univ. of Missouri Agr. Expth. Sta. Spec. Rept. 59: 31p.

SCHWASSMANN, H.O. 1971. Biological rhythms, p.371-428. In: W.S. HoAR \& D.J. Randall. (Eds). Fish Physiology. London, Acad. Press, vol. 6, 559p.

Silva, H.C.; G.H.S. MEdinA; E. FANTA \& M. BACILA. 1993. Sub-lethal effects of the organophosphate Folidol 600 (Methyl Parathion) on Callichthys callichthys (Pisces, Teleostei). Comp. Biochem. Physiol. 105C (2): 197-201.

SPIESER, O.H. 1978. Zentralnervöse und periphere Wirkung von 2,2'-und 4-4'Dichlorbiphenyl sowie Clophen A50 bei Fischen. GSF Ber. Tox. 71: 72-87.

SwIFT, D.R. 1965. Activity cycles in the Brown Trout (Salmo trutta L.) I. Fish feeding naturally. Hydrobiologia 20 (3): 241-247.

THORPE, J.E. (ed) 1978. Rhythmic activity of Fishes. London, Acad. Press., 185p. Welty, J.C. 1934 Experiments in group behavior of fishes. Physiol. Zool. 7: 85-128.

Recebido em 26.IX.1996; aceito em 19.V.1997. 